\title{
Inauguracja prezydentury Andrzeja Dudy jako zespół roszczeń legitymizacyjnych
}

\begin{abstract}
Streszczenie: W niniejszym artykule autorka analizuje specyficzny fakt polityczny, jakim jest inauguracja prezydentury we współczesnym systemie demokratycznym. Koncentrując się na przykładzie inauguracji prezydentury Andrzeja Dudy, autorka odpowiada na pytanie czy ten rozbudowany zespół działań (złożony z aktu zaprzysiężenia, działań symbolicznych, orędzia i innych przemówień) stanowi element świadomie konstruowanego roszczenia legitymizacyjnego, wysuwanego przez prezydenta-elekta. Odpowiadając pozytywnie na to pytanie, ukazuje ona w jaki sposób roszczenia nawiązujące do wszystkich trzech Weberowskich typów legitymizacji zostały wplecione w poszczególne części inauguracji: zaprzysiężenie zawiera więc legalny element uprawomocniający, bardzo rozbudowany kompleks działań symbolicznych - odwołania do tradycji (II i IV RP), natomiast orędzie - wprowadza kolejny typ uzasadnienia legitymizacyjnego - tym razem wynikającego z roszczenia sukcesji charyzmy po Lechu Kaczyńskim.
\end{abstract}

Słowa kluczowe: rytuały polityczne, legitymizacja polityczna, prezydentura, Andrzej Duda

\section{Wprowadzenie}

$\mathbf{I}$ nauguracja prezydentury jako przedmiot badań nauk społecznych należy do tych szczególnych przypadków, które wyjątkowo wyraziście ilustrują zależność pomiędzy przyjętą przez badacza perspektywą teoretyczną (oraz wynikającą z niej metodą badawczą) a wypracowanymi za ich pomocą wnioskami eksplanacyjnymi. Różnorodny wachlarz ujęć, składający się z opracowań antropologicznych (Novak, 1974), historycznych (Sibora, 2010) czy prawniczych tworzy wrażenie sprawdzonych matryc badawczych, „gotowych” do wykorzystania przez politologię. Nauka o polityce, w tej sytuacji, często ulega owej pokusie „dosłownej” implementacji narzędzi badawczych innych dyscyplin bądź to kopiując modele antropologiczne, bądź to stosując w niezmienionej postaci wzor- 
ce nauk prawnych, co prowadzić może nie tylko do nieprzystawalności i rozbieżności wypracowanych wniosków, ale przede wszystkim utraty głębi eksplanacyjnej: pomijania aspektów badawczych specyficznych dla politologii bądź wypracowywania konkluzji niepełnych z punktu widzenia nauki o polityce. Tymczasem, chociaż inauguracja prezydentury jest wspólnym przedmiotem badań dla wszystkich wymienionych dyscyplin, problemy badawcze, jakie implikuje nie są tożsame ${ }^{1}$. Dlatego też punktem wyjścia przy konstruowaniu rozwiązań zapobiegających wymienionym wyżej skutkom jest określenie istoty perspektywy politologicznej oraz dostosowanie do niej adekwatnych narzędzi badawczych.

W niniejszym opracowaniu przyjęto, że specyfika ujęcia politologicznego wynika przede wszystkim z faktu, że inauguracja prezydentury stanowi wydarzenie konstytuujące nowy porządek polityczny, to znaczy tworzące nową sieć relacji władczych (wewnątrz- i międzypaństwowych). Szczególny charakter tego wydarzenia (regulowanego prawnie w stosunkowo wąskim zakresie samego aktu zaprzysiężenia) polega na tym, że jego przebieg i charakter w dużym stopniu zależy od konkretnego prezydenta-elekta, który - podejmując decyzję o poszczególnych elementach ceremonii - daje wyraz swoim wyobrażeniom o tym, jakie są źródła jego uprawomocnienia (Orzechowski, 1984, s. 328).

Kluczowa dla politologicznej problematyzacji interesującego nas przedmiotu okazuje się zatem kategoria legitymacji politycznej, a dokładniej jej szczególna odmiana - „legitymizacja odgórna”, opisywana przez T. Biernata jako sytuacja, w której ,podmiot władczy, dąży do ukształtowania szczególnego rodzaju relacji pomiędzy nim samym a innym podmiotem, dlatego rości sobie prawo, ze względu na swoją przewagę w tych stosunkach [...] do nadawania im szczególnej treści i formy.

${ }^{1}$ Analiza faktu polityczno-prawnego, jakim jest inauguracja prezydentury, jest przykładem takiej sytuacji badawczej, w której dwa imperatywy konstruowania problemu badawczego (oraz podejmowania interpretacji badawczej): problematyczność i niejasność są wyraźnie odmiennie identyfikowane z punktu widzenia politologii oraz np. prawa, co wpływa na znaczące różnice w wypracowywanych wnioskach. Skoro ,interpretowalność ujawnia się badaczowi z jednej strony w postaci obcości, niejasności, nieokreśloności, a z drugiej w postaci wyczuwania problemów tkwiących w przedmiocie i możliwości ich rozjaśniania i dookreślenia", zatem atrakcyjność interpretacyjna/badawcza inauguracji prezydentury okazuje się nikła w perspektywie prawnej (zredukowany do legalności zaprzysiężenia przedmiot badań może nie wydawać się ani nadmiernie problematyczny, ani niejasny), lecz jednocześnie wysoka w przypadku politologii, która uwzględnia wszystkie - nie tylko prawne - normy o charakterze politycznym (Buksiński, 1991, s. 20). 
W tym celu [...] wykorzystuje [...] fakty występujące w obrębie tego stosunku lub w jego otoczeniu dla jego usprawiedliwienia i uzasadnienia swoich przewag. [...] Działania podmiotu władczego mogą być również zorientowane na wytworzenie takich faktów, które w stosunkach panowania będą wykorzystywane jako uzasadniające czy usprawiedliwiające" (Biernat, 2003, s. 90).

Przyjmując - ze świadomością wszystkich jej mankamentów, gruntownie opisanych w literaturze (Andreski, 1992) - klasyczną Weberowską typologię prawomocności (Weber, 2002, s. 158-204) jako ogólną ramę teoretyczną rozważań (uzupełnianą - w miarę potrzeby - o inne, komplementarne koncepcje), problem powyższy sprowadzić więc możemy do pytania o to, na jakiego typu fundamentach legitymizacyjnych (legalnych, tradycyjnych czy charyzmatycznych) opiera się inauguracja prezydentury oraz $\mathrm{w}$ jakiej relacji pozostają względem siebie owe elementy uprawomocniające.

Uwaga badawcza skoncentruje się więc na kwestii w jaki sposób inauguracja prezydentury (w interesującym nas przypadku - prezydentury Andrzeja Dudy) stanowi element świadomie konstruowanego roszczenia legitymizacyjnego, wysuwanego przez prezydenta-elekta. Takie ujęcie - uwzględniające złożoność i emergencję inauguracji jako faktu politycznego - pozwala jednocześnie na wskazanie różnic pomiędzy konkretnymi wydarzeniami tego typu odbywającymi się w danym systemie politycznym, w tym na ukazanie specyfiki inauguracji prezydentury Andrzeja Dudy, jaka odbyła się 6 sierpnia 2015 roku.

\section{Inauguracji prezydentury Andrzeja Dudy - wymiar formalnoprawny}

Elementem wspólnym, łączącym wszystkie tego typu wydarzenia we współczesnym polskim systemie politycznym jest konstytutywny moment zaprzysiężenia, który jest jedynym wymogiem dotyczącym prawnie skutecznego objęcia urzędu Prezydenta RP. Złożenie przysięgi i objęcie urzędu następują zawsze koincydentnie, zatem ,przysięga sama w sobie nie jest [...] podstawą prawną legitymującą działania władcze prezydenta wobec innych organów, lecz poprzez jej złożenie dochodzi do aktualizacji kompetencji wyrażonych w poszczególnych przepisach ustawy zasadniczej i ustaw zwykłych" (Maroń, 2012b, s. 184; por. Sarnecki, 1999, s. 65).

Akt złożenia w Polsce przez prezydenta-elekta przysięgi przed Zgromadzeniem Narodowym jest regulowany prawnie przez art. 130 Kon- 
stytucji RP z dnia 22 kwietnia 1997 roku (rota przysięgi), ustawę z dnia 5 stycznia 2011 r. - Kodeks wyborczy (Dz. U. Nr 21, poz. 112), określającą termin zaprzysiężenia oraz uchwałę Zgromadzenia Narodowego z dnia 6 grudnia 2000 r. Regulamin Zgromadzenia Narodowego zwołanego $w$ celu złożenia przysięgi przez nowo wybranego Prezydenta Rzeczypospolitej Polskiej (M.P. 2000, Nr 40, poz. 774), która dotyczy trybu realizacji tej czynności polityczno-prawnej.

W tym wąskim (formalno-prawnym kontekście) zaprzysiężenie prezydenta Andrzeja Dudy nie różniło się w istotny sposób od tego typu aktów, składanych przez wcześniejszych prezydentów III RP. Pomimo zmieniających się regulacji prawnych (Górecki, 1996, s. 9-22), formalnoprawne źródła konstytutywności, właściwości i tryb składania tego uroczystego przyrzeczenia pozostały takie same. Andrzej Duda - podobnie, jak jego powojenni poprzednicy - złożył więc publicznie przysięgę o charakterze promissoryjnym ${ }^{2}$, powtarzając za marszałkiem $\mathrm{Sejmu}^{3}$ rotę określoną w art. 130 Konstytucji oraz uzupełniając ją o fakultatywną inwokację „Tak mi dopomóż Bóg”. Badacze podkreślają, że współczesny laicki charakter przyrzeczenia (por. Moroń, 2012a, s. 167169) - różniący je w zasadniczy sposób od przyrzeczenia składanego w Polsce w okresie międzywojennym - nie ulega zmianie na skutek wypowiedzenia wspomnianej inwokacji: ,dodanie przez zainteresowanego przedmiotowego zdania nie przekształca składanej przysięgi (ślubowania) w przysięgę wyznaniową [...] Wskazuje jedynie na religijną motywację przy podejmowaniu określonego zadania; nie można jednak twierdzić, że wykluczają motywację religijną ci, którzy owych słów nie dodają" (Mezglewski, 2011, s. 17).

W interesującej nas ,perspektywie legitymizacyjnej”, konstatacja taka okazuje się istotna $\mathrm{z}$ wielu powodów. Po pierwsze, laicki charakter przysięgi wypływa z faktu, że jej treść potwierdza (i zarazem kształtuje) konstytucyjne zobowiązania, przypisane urzędowi prezydenta. Moc legitymizacyjna zaprzysiężenia - w tym faktu zaprzysiężenia Andrzeja Dudy - wynika ze zgodności z normami prawnymi, regulującymi urząd prezydenta w Polsce, stanowi zatem przypadek klasycznej Weberowskiej legalności. Interpretując ten typ legalności w duchu Beethamowskiej le-

2 Zaprzysiężany zapewnia o dotrzymaniu składanych zobowiązań pro futuro.

${ }^{3}$ G. Moroń zwraca uwagę, że taki tryb składania przysięgi nie jest powszechnie praktykowany w Europie. Z wyjątkiem Polski i Chorwacji, większość europejskich prezydentów samodzielnie deklamuje treść przysięgi, natomiast w USA prezydent powtarza rotę za przewodniczącym Sądu Najwyższego (Moroń, 2012b, s. 177). 
gitymizacji na podstawie reguł (Beetham, 1995, s. 288-303), źródeł prawomocności doszukiwać się możemy w tym przypadku nie tylko w (prawidłowo zrealizowanych) wymienionych normach dotyczących samej instytucji zaprzysiężenia, ale również szerzej w regulacjach odnoszących się do wyborów prezydenta.

Po drugie, państwowocentryczna w swym charakterze rota eksponuje polityczność zaprzysiężenia, co otwiera perspektywę badawczą na te elementy, które polityczność kreują (Karwat, 2010, s. 63-88), choć nie są konstytutywne w sensie prawnym. Oprócz dodanej przez prezydenta Andrzeja Dudę wspomnianej inwokacji „Tak mi dopomóż Bóg”, taki charakter mają polityczne normy obyczajowe, określające sytuację zaprzysiężenia. Chociaż pozostają one nadal w polskich realiach in statu nescendi, znaczenie polityczne należy przypisać obecności na posiedzeniu Zgromadzenia Narodowego 6 sierpnia 2015 nie tylko ustępującego prezydenta Bronisława Komorowskiego, ale również wszystkich żyjących poprzedników prezydenta Andrzeja Dudy: Lecha Wałęsy i Aleksandra Kwaśniewskiego. Zwyczaj ten jest stosunkowo nowym wzorcem, wprowadzonym od prezydentury Lecha Kaczyńskiego ${ }^{4}$ i - jak należy domniemywać z wcześniejszej praktyki - dotyczy jedynie prezydentów wybranych w wyborach bezpośrednich (Wojciech Jaruzelski, nie otrzymawszy zaproszenia, nie brał udziału w żadnej z późniejszej inauguracji). Polityczne znaczenie tej normy polega więc na symbolicznym kreowaniu ciągłości władzy politycznej i jednocześnie na dokonaniu aktu historycznej demarkacji, a nawet symbolicznej ekskluzji.

W podobnym duchu należy odczytywać sposób składania przysięgi przez Andrzeja Dudę, który stanowił odtworzenie postawy L. Kaczyńskiego i B. Komorowskiego. Prezydenci ci przyjmowali postawę na baczność, natomiast wcześniejsi poprzednicy przysięgali z prawą ręką uniesioną w geście salutu. Powojenni prezydenci nie powrócili do zwyczaju umieszczania dłoni na tekście konstytucji (jej egzemplarz leży na stole prezydialnym), co - jak podkreślają badacze - „zwiększyłoby solenność ceremonii" (Moroń, 2012b, s. 178). Chociaż pewne kroki w kierunku podkreślenia podniosłości tego elementu zostały wykonane (pojawił się - zamówiony wcześniej przez marszałka Sejmu Radosława Sikorskiego - egzemplarz konstytucji, ręcznie wykaligrafowany przez artystkę Ewę

${ }^{4}$ W 2005 roku, na zaprzysiężeniu Lecha Kaczyńskiego obecni byli prezydenci R. Kaczorowski, L. Wałęsa i A. Kwaśniewski; w 2010 roku prezydenci: L. Wałęsa i A. Kwaśniewski. W inauguracji prezydentury L. Wałęsy nie wziął udziału W. Jaruzelski, podobnie w 1995 i 2000 nieobecni byli W. Jaruzelski i L. Wałęsa. 
Landowska), Andrzej Duda nie zdecydował się na wprowadzenie innych zmian w tym punkcie ceremonii zaprzysiężenia.

\section{Inauguracji prezydentury Andrzeja Dudy - wymiar symboliczny}

Ponadto, dodanie inwokacji „Tak mi dopomóż Bóg” należy odczytywać nie tylko jako wskazanie na religijne motywacje zaprzysiężonego, ale przede wszystkim jako przesłankę świadczącą o tym, że prezydentelekt zamierza oprzeć roszczenia legitymizacyjne również na argumentacji wykraczającej poza uzasadnienia formalnoprawne (proceduralne). Chociaż przesłanka ta nie zawsze okazywała się uzasadniona (z wyjątkiem W. Jaruzelskiego oraz A. Kwaśniewskiego wszyscy powojenni prezydenci przywoływali formułę „Tak mi dopomóż Bóg”), w przypadku inauguracji prezydentury Andrzeja Dudy wydaje się trafna, ponieważ sam akt zaprzysiężenia został „obudowany” przez wyjątkowo bogaty zespół działań symbolicznych. Do momentu (drugiego) zaprzysiężenia Aleksandra Kwaśniewskiego, powojenne inauguracje posiadały (formalnie) skromną oprawę symboliczną, a działania tego typu, jak np. złożenie kwiatów przed zaprzysiężeniem przez Lecha Wałęsę pod Pomnikiem Małego Powstańca na Starym Mieście, jego udział w mszy w archikatedrze św. Jana czy udział A. Kwaśniewskiego (1995) w wieczerzy wigilijnej z żołnierzami (Pożegnanie, 2015), nie traktowano jako „oficjalnych” składowych uroczystości. Inauguracje ograniczały się niemal wyłącznie ${ }^{5}$ do aktu zaprzysiężenia, dlatego też legalizm był jedynym (przez to czytelnym i łatwo identyfikowalnym) argumentem legitymizacyjnym.

Istotne w tej perspektywie zmiany nastapiły w 2005 roku, kiedy wprowadzono nowy (przygotowany przez Tomasza Orłowskiego na polecenie Lecha Kaczyńskiego), rozbudowany symbolicznie scenariusz ceremonii. W zamyśle autorów miał nawiązywać w wybranych punktach do przedwojennego, szczegółowego ceremoniału państwowego, opracowanego

5 Wyjątkiem była sytuacja, kiedy w 1990 roku L. Wałęsa otrzymał od Prezydenta RP na uchodźctwie Ryszarda Kaczorowskiego insygnia władzy prezydenckiej z czasów II RP (Choragiew Rzeczpospolitej, pieczęć Kancelarii Prezydenta, rękopis Konstytucji kwietniowej oraz insygnia Orderu Orła Białego). A. Kwaśniewski tych uroczystości już nie rekonstruował, natomiast w 2000 roku dodał jako jedyny element symboliczny uroczyste objęcie zwierzchnictwa nad wojskiem. Ani w pierwszym, ani w drugim przypadku, elementy te jednak nie naruszały koncepcji legitymizacji opartej na zgodności z procedurami (legalizmie) (Mojak, 1994, s. 179 i n.) 
na tego typu okazję przez Stefana hr. Przeździeckiego (Sibora, 2010, s. 90) i kreować - ponownie - wrażenie historycznej ciągłości władzy politycznej. Taki sam cel przyświecał wspomnianemu autorowi przedwojennego ceremoniału, dla którego inspiracją były koronacje królewskie z czasów I RP, podczas których uprawomocnienie dokonywało się na mocy „boskiego namaszczenia”. W przedwojennym scenariuszu, argumentacja odwołująca się do „woli boskiej” czy „boskiego namaszczenia” stanowiła przykład klasycznej Weberowskiej legitymizacji tradycyjnej i znalazła przełożenie w postaci licznych nawiązań religijnych, natomiast najpełniejszy jej wyraz stanowił religijny i wyznaniowy charakter ówczesnej roty przysięgi: „Podmiotem, któremu się ją nominalnie składało, był bowiem Bóg. Wobec natomiast Narodu, prezydent zaciagał identyczne treściowo zobowiązanie artykułowane i werbalizowane słowem «ślubuję». [...] Odwołanie się do Trójcy Świętej oraz męki Syna Bożego ujawniało chrześcijańską afiliację instytucji zaprzysiężenia" (Moroń, 2012b, s. 161). W ten sposób - podczas prezydenckiej inauguracji - legalizm został spleciony z tradycyjną argumentacją legitymizacyjną i w takiej właśnie złożonej, wielowymiarowej formule pojawił się w rekonstruowanym ceremoniale.

Opisany mechanizm stanowi ilustrację zjawiska zapożyczenia prawowitości, polegającego na tym, że ,nowy system polityczny pożycza prawowitość od starego poprzez pielęgnowanie starych form symbolicznych, ale przekierowanych na nowe cele" (Kertzer, 2010, s. 67). W analizowanym przez nas przypadku, owo zapożyczenie jest realizowane za pomocą specyficznej sekwencji symbolicznej, w której prezydent III RP, chcąc nawiązać do wzorców II RP, adoptuje symboliczne schematy legitymizacyjne z I RP, które to schematy w II RP zostały przysposobione w zmodyfikowanej formie ${ }^{6}$. Kolejni prezydenci, podejmując decyzje dotyczące uroczystości inauguracyjnych, nolens volens musieli odnieść się do opisanej sekwencji symbolicznej: Bronisław Komorowski przyjął taktykę kontynuacji symbolicznej w zredukowanej jednak formie ${ }^{7}$, na-

${ }^{6}$ D. Kretzer mechanizm ten wyjaśnia poprzez analogię genetyczną, pisząc, iż osobliwe zróżnicowanie symboliczne jest wynikiem zarówno przechodzenia symboli z jednego schematu do drugiego (odpowiednik dryfu genetycznego - przechodzenia osobników jednej populacji do następnej), jak i spontanicznej innowacji (odpowiednik mutacji genetycznej), prowadzącej do „symbolicznej wynalazczości” (Kertzer, 2010, s. 248).

7 Uroczyste przejęcie zwierzchnictwa nad siłami zbrojnymi nie miało miejsca w dniu inauguracji, lecz odbyło się w dniu Święta Wojska Polskiego; natomiast - po- 
tomiast Andrzej Duda nie tylko powtórzył scenariusz ceremonii z 2005 roku, lecz wprowadził dodatkowo nowe elementy oraz rozbudował już istniejące.

Nowym elementem, wprowadzonym do ceremonii inauguracyjnej w 2015 roku było przejście pieszo pary prezydenckiej z Placu Piłsudskiego (po przejęciu zwierzchnictwa nad wojskiem) do Pałacu Prezydenckiego, zakończone wystapieniem prezydenta do osób zgromadzonych przed Pałacem. Praktyka taka - prawdopodobnie wzorowana bezpośrednio na amerykańskich paradach inauguracyjnych - stanowiła przejaw pewnej „innowacji” (nie miała bowiem swojego polskiego przedwojennego odpowiednika, choć posiadała bogate odniesienia historyczne ${ }^{8}$ ), służącej między innymi realizacji funkcji fatycznej. Świadczy o tym uzasadnienie (zawarte w oficjalnej zapowiedzi, przygotowanej przez kancelarię prezydenta dla prasy), w której podano, iż prezydent Duda podczas spaceru „będzie dziękował ludziom i pozdrawiał zgromadzonych” (Wiszowaty, 2015). Temu samemu celowi - utrzymaniu/nawiązaniu kontaktu ze społeczeństwem - służyło również kolejne novum - spotkanie z internautami za pomocą - prowadzonej na żywo - transmisji wideo, które stanowiło ostatni punkt uroczystości inauguracyjnych. Chociaż - jak się wydaje - podtrzymaniu kontaktu w analizowanej inauguracji przypisywano większe znaczenie, niż u poprzedników (na co wskazuje dodatkowo „rekordowa" liczba pięciu przemówień wygłoszonych przez Andrzeja Dudę w tym dniu) pamiętać należy, iż funkcja fatyczna pełniła w opisywanym kontekście rolę komplementarną względem dominującej funkcji ekspresywnej. Rozbudowa ceremoniału symbolicznego, jak i realizacji wspomnianego bloku wystąień, była podyktowana przede wszystkim potrzebą szeroko rozumianej ekspresji, w tym potrzebą ukazania własnej wizji prawomocności władzy.

Istotnymi składowymi tejże wizji, odtworzonymi zgodnie z wcześniejszym wzorcem ceremonii, były: msza w archikatedrze warszawskiej, odbywająca się na Zamku Królewskim uroczystość ustanowienia Prezydenta RP Wielkim Mistrzem Orderów Orła Białego i Polonia Restituta oraz wizyta w Pałacu Prezydenckim, gdzie na dziedzińcu Pała-

dobnie, jak poprzednik - prezydent uczestniczył w mszy w archikatedrze warszawskiej oraz w uroczystym przekazaniu insygniów Orderu Odrodzenia Polski i Orderu Orła Białego, złożył również kwiaty w Sejmie pod tablicą upamiętniającą parlamentarzystów poległych w czasie II wojny światowej.

${ }^{8}$ Geertz opisując rozmaite historyczne przykłady objazdów królewskich podkreśla, iż służyły one królowi do ,prezentacji swojej władzy sceptykom” (Geertz, 2005, s. 139). 
cu prezydent przyjął meldunki od dowódcy garnizonu oraz szefa BOR. Rozbudowane zostały natomiast dwa segmenty uroczystości, a mianowicie ceremoniał wojskowy oraz ,wątek” kommemoratywny. Wojskowa część uroczystości została rozszerzona według wzorca przedwojennego i obejmowała m.in. takie elementy jak opuszczenie (dzień przed inauguracją) Proporca Prezydenta RP do połowy masztu i jego podniesienie w dniu inauguracji na maszcie przed Grobem Nieznanego Żołnierza, asystę reprezentacyjnego szwadronu kawalerii przy wjeździe prezydenta na Plac Piłsudskiego, odebranie honorów od poszczególnych rodzajów sił zbrojnych, oddanie czci sztandarowi wojskowemu, wreszcie - zamykającą uroczystość - defiladę wojskową (Wiszowaty, 2015). Z kolei bardzo rozbudowany „segment kommemoratywny” obejmował złożenie przez prezydenta podczas inauguracji trzech wiązanek kwiatów w Sejmie: pod tablicą upamiętniającą Macieja Płażyńskiego, pod tablicą upamiętniającą posłów i senatorów - ofiary katastrofy smoleńskiej, następnie parlamentarzystów poległych podczas II wojny światowej; złożenie kwiatów w krypcie archikatedry warszawskiej - na grobach prezydentów Gabriela Narutowicza, Ignacego Mościckiego, Stanisława Wojciechowskiego, Ignacego Paderewskiego oraz prymasa Józefa Glempa i przed sarkofagiem prymasa Stefana Wyszyńskiego; w Pałacu Prezydenckim - przed tablicą upamiętniającą Prezydenta Lecha Kaczyńskiego i jego małżonkę, Prezydenta Ryszarda Kaczorowskiego oraz pracowników Kancelarii Prezydenta RP, którzy zginęli w katastrofie smoleńskiej; wreszcie - złożenie wiązanki pod Grobem Nieznanego Żołnierza.

Przedstawiony powyżej ceremoniał inauguracyjny, składający się z sieci złożonych, heterogenicznych elementów symbolicznych, tworzy "gęstą" (Geertz, 2005), lecz skonsolidowaną strukturę symboliczną dzięki szczególnym - opisanym przez Turnera - właściwościom, charakterystycznym dla tego typu fenomenów, to znaczy kondensacji znaczeń, wieloznaczności (multivocality) oraz niejasności (ambiguity) (Turner, 2007, s. 63). Paradoks tak ukonstytuowanej struktury polega na tym, że wyjaśnienie jej treściowej oryginalności (wynikającej z wzajemnego oddziaływania poszczególnych elementów) wymaga analitycznej ... dekompozycji. W analizowanym przypadku, zabieg ten pozwala na wyróżnienie trzech silnie splecionych, dominujących wiązek symbolicznych, na które składają się: ,pasmo” katolickie, tradycja II Rzeczpospolitej oraz symbolika IV RP ${ }^{9}$, nie rozstrzyga

${ }^{9}$ IV Rzeczypospolita w niniejszym artykule jest rozumiana jako „znak i treść tego znaku, ponieważ została przez określone kody powołana do życia. Istnieje tak samo, jak istnieje 'renesans', 'katolicyzm', 'polskość', co więcej - istnieje tak samo, 
on jednak w pełni, w jakich zależnościach składowe te pozostają względem siebie. Rozwiązanie tego dylematu - ważnego z punktu widzenia roszczeń legitymizacyjnych - przynoszą klasyczne ustalenia teoretyczne oraz treści zawarte w przemówieniach, wygłaszanych w dniu inauguracji przez Andrzeja Dudę.

Badacze rytuałów i ceremonii jako szczególnego typu działań symbolicznych zgodnie podkreślają, że immanentną cechą tego typu aktywności jest - wpisana w jej strukturę - kategoria sacrum. Przyjmują oni, że świętość jest trwale obecna w działaniach symbolicznych, również tych o charakterze świeckim (Bellah, 1967, s. 2-21). Obecność ta dotyczy zarówno poziomu treści (poprzez odniesienie do - rozmaicie rozumianego - „najwyższego”), formy (obrzędowości wzorowanej na religijnej), a nawet struktury (poprzez organizację i czasu, i przestrzeni w opozycji do profanum). Nasycenie działań symbolicznych sacrum jest właściwością stopniowalną, wprost proporcjonalną do performatywności przypisywanej tego typu aktywności przez podmiot działający, dlatego też im intensywniejsza jest jej obecność (im bardziej ceremoniał przekształca się w rytuał), tym silniejsze bywa przekonanie o kreacyjnej (transformacyjnej) mocy tej struktury.

W świetle powyższych ustaleń, elementy katolickie zawarte w uroczystościach inauguracyjnych prezydenta Andrzeja Dudy (takie jak msza w archikatedrze czy obecność dostojników kościelnych podczas zaprzysiężenia) należałoby odczytywać przede wszystkim jako - uwarunkowaną kulturowo - wersję rudymentarnego sacrum, należącą do podstawowego arsenału środków symbolicznych obecnych w polskiej rzeczywistości społeczno-politycznej. Stanowią one element nieswoisty w tym sensie, że stosowane powszechnie podczas różnego typu aktywności publicznych, podejmowanych w Polsce (od uroczystości otwarcia, poprzez ceremonie rocznicowe, na pogrzebach kończąc); są jednocześnie elementami inauguracji na tyle ugruntowanymi, że mówią więcej o obowiązującym systemie aksjo-normatywnym, niż o przekonaniach zaprzysiężanych (choć -paradoksalnie - brak tych elementów w ceremonii można traktować jako silną przesłankę, dotyczącą indywidualnych preferencji konkretnego prezydenta, np. Aleksandra Kwaśniewskiego). Biorąc pod uwagę wyróżnione wyżej trzy poziomy obecności sacrum, dostrzec możemy wyraźnie, że w opisywanym przypadku, katolicki wariant świętości jest najsilniej

jak istnieje 'jednorożec', albowiem także ten znak - mimo, iż nie posiada żadnego odpowiednika w świecie pozajęzykowym, jest pewną - ustrukturyzowaną przez kod i rozpoznawalną za sprawą kodu - jednostką kulturową" (Czerwiński, 2010, s. 71). 
zarysowany na poziomie formy (m.in. poprzez bezpośrednią, dosłowną implementację w ceremoniał inauguracyjny obrządku mszy czy obrządku nawiedzania grobów), dalej: struktury (typowe - dla mechanizmów obecnych w „religiach cywilnych” - kreowanie odświętności dnia poprzez przygotowanie i upublicznienie szczegółowego planu uroczystości oraz tworzenie topografii wyróżnionych miejsc - „wyjętych”, oddzielonych od rutyny dnia codziennego), w najmniejszym zaś stopniu na poziomie treści, ponieważ brak jest odwołań do podmiotu transcendentnego. Taki rodzaj usytuowania sacrum w strukturze uroczystości inauguracyjnej - intensywny i bezpośredni w formie, pośredni w strukturze, natomiast nieobecny $\mathrm{w}$ treści - potwierdza tezę, iż podmioty zaangażowane nie przypisują tym działaniom mocy performatywnej, lecz jedynie sens społeczno-symboliczny (Buchowski, 1991, s. 220), zatem mamy w tym przypadku do czynienia z ceremonią (a nie rytuałem), podczas której przywoływanym argumentem legitymizacyjnym jest (Weberowsko rozumiana) tradycja.

\section{Inauguracji prezydentury Andrzeja Dudy - wymiar językowy}

O niepowtarzalności analizowanej ceremonii inauguracyjnej nie przesądza jednak li tylko specyficzne położenie sacrum, lecz relacja pomiędzy dwoma pozostałymi wątkami symbolicznymi, funkcjonującymi na tym chrześcijańskim tle, czyli tradycją II Rzeczpospolitej oraz symbolami IV RP. Te dwa zespoły elementów - współobecne (a nawet wyraźnie powiązane) w wymienionych wyżej działaniach symbolicznych - nie są jednak względem siebie równorzędne. Kluczem służącym do rozkodowania hierarchii tych składowych okazuje się analiza treści przemówień, wygłaszanych przez Andrzeja Dudę w dniu zaprzysiężenia, a przede wszystkim interpretacja prezydenckiego orędzia inauguracyjnego. $\mathrm{W}$ interesującym nas kontekście, jego szczególna wartość eksplanacyjna wynika nie tylko z utrwalonej formalnie i zwyczajowo rangi politycznej, ale $\mathrm{z}$ możliwości przedstawienia w nim indywidualnej, autorskiej wizji rzeczywistości politycznej (obecnej i postulowanej).

W „orędziu” Andrzeja Dudy ten rys indywidualny jest wyraźnie obecny w warstwie treściowej (oraz - wymagającej odrębnego opisania - językowej) i został zbudowany poprzez ekspozycję wątku osobistego doświadczenia. To „osobiste doświadczenie” jako motyw przewodni analizowanej wypowiedzi jest w niej rozwijany w dwóch zasadniczych 
formach: w licznych odniesieniach do spotkań z wyborcami („Byłem, rozmawiałem w Londynie, w Brukseli, w innych miejscach") ${ }^{10}$ oraz w nawiązaniu do autorytetu, które pojawiło się już na początku wystąpienia: ,[...] w szczególności podziękować chciałem temu prezydentowi, którego nie ma już pośród nas. Chciałem podziękować panu prezydentowi profesorowi Lechowi Kaczyńskiemu. [...] kiedyś przed laty zaprowadziła mnie do niego droga mojego wychowania, mojego przygotowania uniwersyteckiego, mojego doktoratu. Zaprowadziła mnie ona do niego i wtedy obok niego dojrzewałem do polityki, polityki rozumianej jako troska o dobro wspólne, w znaczeniu dobra narodu, dobra polskiego państwa, państwa sprawiedliwego, w którym wszyscy obywatele traktowani są równo, które broni słabszych i nie musi bać się silnych" (Orędzie prezydenta, 2015).

Przywołana już w 90 sekundzie orędzia argumentacja odwołująca się do bezpośredniego doświadczenia pracy ucznia Andrzeja Dudy z mistrzem Lechem Kaczyńskim wprowadza kolejny typ uzasadnienia legitymizacyjnego - tym razem wynikającego z roszczenia sukcesji charyzmy. Pozycjonowanie siebie w roli ewentualnego następcy Lecha Kaczyńskiego stanowi wyjątkowo ważki (i ważny, i drażliwy) argument uprawomocniający w subiektywnej perspektywie pretendenta (który oparł na nim swoją kampanię wyborcza), ale także w perspektywie badacza, demaskującego kody symboliczne zawarte w działaniach inauguracyjnych.

Ten centralny argument legitymizacyjny nastręcza jednak pewnych trudności zarówno podmiotowi go formułującemu, jak i interpretatorowi. Pierwsza trudność dotyczy konstrukcji tego szczególnego uzasadnienia uprawomocniającego, próbującej łączyć dwie sprzeczne przesłanki: pierwsza $z$ nich skłania do eksponowania tego typu argumentacji, co wynika z wyjątkowego (nadrzędnego) znaczenia, przypisywanego roli sukcesora przez Andrzeja Dudę; z kolei druga przesłanka każe stonować tenże komunikat z uwagi na nierozstrzygnięty (natenczas) proces sukcesji

${ }^{10}$ M.in.: „Polacy mówili mi o swoich troskach, mówili mi o swoich problemach, o tym, jakiej Polski by chcieli. Mówili to na moich spotkaniach, wielu ludzi do mnie przychodziło. Ja im odpowiadałem i uczyłem się przy nich również tego, czego dziś potrzebuje Polska. Uczyłem się w sposób bardzo namacalny, bo w bezpośrednim kontakcie z nimi [...]”. We fragmencie kończącym orędzie: „W ostatnich dniach, w ostatnich tygodniach zdarzają mi się takie sytuacje, że podchodzą do mnie ludzie na ulicy i mówią: «dzień dobry, panie prezydencie, nie głosowaliśmy na pana, ale życzymy panu, żeby pan dotrzymał swoich zobowiązań, tego, co pan mówił w kampanii». [...] Wielokrotnie słyszałem, zwłaszcza w czasie kampanii, «niemożliwe, niemożliwe, niech pan nie liczy, niemożliwe» [...]" (Orędzie prezydenta, 2015). 
charyzmy, w którym to procesie Andrzej Duda nie był ani jedynym, ani pewnym kandydatem do „dziedziczenia”. Chęć pogodzenia opisanych przesłanek sprawiła, że nowozaprzysiężony prezydent wystapił z roszczeniem legitymizacyjnym typu charyzmatycznego nie jako sukcesor, lecz jako pretendent do sukcesji. W świetle Weberowskiej koncepcji dziedziczenia charyzmy, zabieg ten wydaje się posunięciem uzasadnionym i „,bezpiecznym”, zważywszy szczególnie na dwie okoliczności wymienione przez klasyka, a mianowicie, po pierwsze: kluczową rolę rządzonych w orzekaniu o następstwie charyzmy - „prawomocność staje się wtedy prawomocnością zyskaną dzięki wyznaczeniu” (Weber, 2002, s. 186); po drugie: różnorodność zasad owego „wyznaczania”, spośród których wskazanie na najbliższego współpracownika pierwotnego charyzmatyka jest tylko jednym z wielu - obok najpowszechniejszego dziedziczenia, objawienia czy namaszczenia (Weber, 2002, s. 185-187) - sposobów rozwiązania problemu sukcesji.

Z kolei z perspektywy badacza, problem dotyczy trudności w ustaleniu jaki sposób rozumienia charyzmy (wąski czy szeroki) przyjął pretendent do sukcesji. Wąskie, Weberowskie pojmowanie tej kategorii wiąże ją ze specyficznym zespołem cech osobowościowych, przypisywanych przywódcy przez rządzonych i postrzeganych przez nich jako nadzwyczajne: „Ludzie poddają się takiemu przywódcy, bowiem poddają się wierze w te zjawiska, które potwierdzają jego nadzwyczajne cechy" (Bendix, 1975, s. 269). Natomiast szersze rozumienie - efekt Shilsowskiej reinterpretacji Webera (Shils, 1965, s. 199) - idzie w kierunku wiązania jej z intensywnym występowaniem jakiegoś fundamentalnego elementu, który ,jest uosobieniem czegoś bardzo poważnego, w sensie Durkheimowskim, co jest uznawane, a następnie staje się [elementem - dop. M.K.] centralnym i zasadniczym dla ludzkiej egzystencji, [...] centralność zespolona z intensywnością czyni to »coś czymś niezwykłym” (Biernat, 2003, s. 163-164).

W analizowanych uroczystościach inauguracyjnych odnajdziemy przejawy stricte Weberowskiego („osobowego”) ujęcia charyzmy szczególnie w tych fragmentach (jak np. cytowany wyżej), w których Andrzej Duda explicite przywołuje swoje bezpośrednie spotkania z Lechem Kaczyńskim, ale również liczne przykłady rozszerzonego pojmowania charyzmy - tam, gdzie Lech Kaczyński pojawia się jako figura symboliczna, a nie osoba. Najważniejszymi przejawami takiego myślenia było - wspomniane wcześniej - odtworzenie przez nowozaprzysiężonego prezydenta scenariusza uroczystości inauguracyjnej, opracowanego dla Lecha Ka- 
czyńskiego oraz uzupełnienie owego scenariusza o elementy, w których Lech Kaczyński funkcjonuje zarówno jako współtwórca, jak i symbol mitologii (rozumianej Lèvi-Straussowsko) IV RP. W ten sposób dochodzimy do wniosku, że obecność w badanej strukturze symbolicznej równie spójnych i równie przekonujących przykładów różnego pojmowania charyzmy nie pozwala nam jednoznacznie orzec o sposobie jej postrzegania przez Andrzeja Dudę, przesądza jednak o innym istotnym fakcie, a mianowicie o prymarności tradycji IV RP względem tradycji II Rzeczypospolitej.

Wpisana w uroczystości inauguracyjne struktura mityczno-symboliczna ma budowę „szkatułkową" - opiera się na licznych, wybieranych selektywnie i poddanych rekompozycji symbolach II RP, dlatego też elementy te sa - w perspektywie odbiorcy - łatwe w identyfikacji. Bezpośrednie nawiązania do okresu międzywojennego zawarte są między innymi w wystąpieniu Andrzeja Dudy podczas uroczystości przejęcia insygniów na Zamku Królewskim, jednak treści te były silnie indukowane kontekstem wypowiedzi, dlatego trudno traktować je jako wiążącą deklarację preferencji aksjologicznych prezydenta. Symbolika II RP jest traktowana selektywnie, pojawiają się tylko te z nich, które wcześniej wybrał i implementował (do scenariusza uroczystości, jak również do mitu IV RP) Lech Kaczyński, stąd - parafrazując A. Giddensa - można powiedzieć, iż obecność symboliki II RP w analizowanych działaniach jest obecnością zapośredniczoną, a medium stanowi figura Lecha Kaczyńskiego.

\section{Wnioski}

Przedstawiona powyżej analiza uroczystości inaugurujących prezydenturę Andrzeja Dudy w 2015 roku pozwala wysnuć trzy podstawowe wnioski, dotyczące różnych wymiarów przeprowadzonej eksplanacji. Pierwszy - najbardziej szczegółowy, odnoszący się do treściowego poziomu analizowanego zjawiska - dotyczy stosunku Andrzeja Dudy do kwestii symbolicznej ciagłości władzy, rozumianej jako demonstrowany w działaniach inauguracyjnych symboliczny związek z poprzednikiem, np. poprzez uroczyste ,przejęcie władzy z rąk poprzednika” albo odwiezienie poprzednika z zachowaniem wszelkich honorów państwowych. Chociaż stosunek do tego problemu jest w znacznej mierze warunkowany tak zwaną uogólnioną kulturą polityczną społeczeństwa, w którym dany prezydent funkcjonuje, to jednak duży zakres swobody, z jaką prezy- 
dent-elekt może kształtować „swoją” uroczystość inauguracyjną pozwala uznać zarysowane tam stanowisko za indywidualną preferencję podmiotu politycznego. W warunkach współczesnej demokracji reguła polityczna odnosząca się do symbolicznej ciągłości władzy uchodzi za jedną z istotniejszych reguł, stąd często przybiera ona charakter imperatywu politycznego, niosącego największy ciężar powinności (Sztompka, 2002, s. 259). Z tego powodu jej przestrzeganie było i jest traktowane jako jeden z podstawowych obowiązków nowo zaprzysiężonego prezydenta nie tylko w USA ${ }^{11}$, ale również w przedwojennej Polsce, gdzie przyjmowano, że „nowoobrany Prezydent w galowym powozie w eskorcie szwadronu przybocznego odwozi ustępującego Prezydenta do jego siedziby prywatnej i powraca do rezydencji Prezydenta Rzeczypospolitej" (Sibora, 2010, s. 384).

W analizowanym materiale badawczym, reguła symbolicznej ciąłości władzy nie jest traktowana przez podmiot rządzący jako bezwzględny imperatyw polityczny i z tego też powodu nie była realizowana w znaczeniu przedstawionym powyżej. Bardzo trudno bowiem doszukać się realizacji funkcji ,uroczystego przejęcia władzy z rąk poprzednika” w spotkaniu Andrzeja Dudy z ustępującym Bronisławem Komorowskim, jakie miało miejsce w sejmie tuż po zaprzysiężeniu, a które jego organizator - dyrektor Biura Obstugi Organizacyjnej Prezydenta - Janusz Strużyna opisał następująco: „Po zakończeniu uroczystości prezydent Komorowski z żoną zejdą z góry, wejdą do pokoju 39, gdzie będzie już prezydent Duda. Kilka sekund dla dziennikarzy i pożegnanie" (Pożegnanie, 2015).

${ }^{11} \mathrm{O}$ znaczeniu przypisywanemu tejże regule przez amerykańskich prezydentów świadczy fakt, że jest ona często wzmacniana dodatkowo poprzez pozaceremonialne gesty ustępującego prezydenta. Znanym przykładem takiego działania jest słynny list, napisany przez George'a Busha seniora do swojego zwycięskiego rywala Billa Clintona, który zostawił dla niego na biurku w Gabinecie Owalnym Białego Domu; list miał następującą treść: „20 stycznia 1993 / Drogi Billu, / Kiedy wszedłem przed chwilą do tego pokoju poczułem ten sam podziw i szacunek, które czułem cztery lata temu. Wiem, że też to poczujesz. / Życzę Ci wiele szczęścia w tym miejscu. Ja nigdy nie odczuwałem tutaj samotności, o której pisali niekiedy byli Prezydenci. / Czekają Cię również trudne chwile. Będziesz poddawany krytyce, którą odbierzesz jako niesprawiedliwą. Nie jestem za dobry w udzielaniu rad, ale przyjmij ode mnie jedną: nie pozwól tym krytykom zniechęcić Cię do działania lub wytrącić z obranego kursu. / Kiedy czytasz ten list, jesteś już NASZYM [podkr. w oryginale - J.B.] Prezydentem. Pamiętaj, że dobrze życzę Tobie i Twojej Rodzinie. / Twój sukces jest odtąd sukcesem naszego kraju. Pamiętaj, że masz we mnie wiernego kibica. / Powodzenia! / George" (Boult, 2016). 
To spotkanie „na zapleczu” głównego nurtu uroczystości świadczy o tym, że reguła ciagłości władzy nie jest również traktowana przez prezydenta Andrzeja Dudę jako preferencja określana zwrotem „dobrze by było, żeby..." (Sztompka, 2002, s. 260), lecz jako rodzaj przyzwolenia, które „wskazuje, że jeśli ktoś by pragnął działać w pewien sposób, to nic nie stoi na przeszkodzie, ale nie jest to także działanie zalecane" (Sztompka, 2002, s. 259-260). Takie odczytanie tej reguły pozwala wyjaśnić nie tylko „zakulisowość” wspomnianego działania, ale również dostrzegalną próbę jej redefinicji, którą można zrekonstruować w sposób następujący: przyzwolenie oznacza prawo nowo zaprzysiężonego do demonstrowania związku niekoniecznie z ustępującym prezydentem, lecz z wybranym dowolnie poprzednikiem, co w praktyce sprawia, że ekspozycja selektywnie pojmowanej ciagłości jest jednocześnie demonstracją zerwania z tradycją, stojącą za pozostałymi.

Wniosek drugi odnosi się do teoretycznego poziomu podejmowanych analiz, a dokładniej wzajemnych relacji pomiędzy przywoływanymi argumentami legitymizacyjnymi. W świetle przedstawionej analizy, inauguracja prezydentury jest strukturą posiadającą jednocześnie wielką objętość symboliczną i ograniczony potencjał komunikowania tychże treści, co oznacza, że dodawanie nowych elementów odbywa się kosztem „widoczności” starych składowych. W przypadku uroczystości inauguracyjnych koncentrujących się jedynie na zaprzysiężeniu i nieposiadających dodatkowej oprawy symbolicznej (np. inauguracja prezydentury Lecha Wałęsy), kwestia charakteru zgłaszanego roszczenia legitymizacyjnego nie pozostawiała wątpliwości. Natomiast w opisywanej wyżej sytuacji struktury o rozbudowanym ceremoniale symbolicznym, wydźwięk roszczenia opartego na legalności zostaje stłumiony poprzez znaczenie silniejszą ekspozycję roszczenia o genezie tradycyjnej i - powiązanego z nim - roszczenia nawiązującego do sukcesji charyzmy. Ta wymuszona (ilością i różnorodnością elementów składowych) hierarchia roszczeń legitymizacyjnych jest - w ścisłym sensie - wyrazem wyobrażeń nowo zaprzysiężonego prezydenta na temat źródeł prawomocności sprawowanej przez siebie władzy, natomiast w szerszym znaczeniu - jest ona również istotnym przejawem wyznawanych preferencji politycznych, co pozwala badaczowi korzystać z zawartego w niej potencjału prewidystycznego. Owa struktura roszczeń legitymizacyjnych nie mówi natomiast nic o obiektywnym poparciu społecznym (efekcie tzw. legitymizacji oddolnej), jakim realnie cieszy się podmiot polityczny. Cum grano salis należałoby więc 
podchodzić do kwestii skuteczności tego typu zabiegów, tym bardziej, że - jak wskazują badacze (Biernat, 2003) - złożoność procesów legitymizacyjnych powoduje, że relacja przyczynowo-skutkowa jest w tym przypadku wyjątkowo trudna do odtworzenia.

Wniosek trzeci, najogólniejszej natury, przywołuje metodologiczny aspekt badań politologicznych. Przeprowadzona wyżej analiza, ukazująca relacje pomiędzy symbolem a rzeczywistością polityczną potwierdza konieczność „ostrożnego” i refleksyjnego korzystania z narzędzi badawczych, wypracowanych przez dyscypliny pokrewne na użytek ich badań. Narzędzia te bowiem pozwalają na uchwycenie rzeczywistości politycznej jedynie wybiórczo - niejako en passant, ponieważ ani historyk, ani prawnik, ani antropolog nie ma obowiązku przedstawienia kompleksowej analizy mechanizmów politycznych. Realizacja tego zadania to racja bytu politologii, lecz tego fundamentalnego obowiązku nie sposób zrealizować bez „otwarcia” na pozaracjonalne i pozainstytucjonalne aspekty rzeczywistości społecznej, ponieważ „to, co symboliczne nie jest jakimś pozostałym wymiarem rzekomo faktycznej polityki, a jeszcze mniej asubstancjalnym ekranem, na który rzeczywiste kwestie rzucane są w formie bladej lub pasywnej. To, co symboliczne jest faktyczną polityką, artykułowaną w sposób szczególny i często najsilniejszy" (Kertzer, 2010, s. 15).

\section{Bibliografia}

Andreski S. (1992), Maxa Webera olśnienia i pomyłki, PWN, Warszawa.

Beetham D. (1995), Legitymizacja władzy, w: Władza i społeczeństwo, red. J. Szczupaczyński, Wydawnictwo Naukowe Scholar, Warszawa.

Bellah R. N. (1967), Civil Religion in America, „Daedalus”, vol. 96, nr 1.

Bendix R. (1975), Max Weber. Portret uczonego, PWN, Warszawa.

Biernat T. (2003), Legitymizacja władzy politycznej. Elementy teorii, Wydawnictwo Adam Marszałek, Torun.

Boult A. (2016), The "magnanimous, bipartisan and dignified" letter George H. W. Bush left for Bill Clinton before leaving office, "The Thelegraph" $\mathrm{z}$ dnia 13.06.2016, http://www.telegraph.co.uk/news/2016/06/13/the-magnanimousbipartisan-and-dignified-letter-george-hw-bush-l, 1.10.2016.

Buchowski M. (1991), Obrzęd-rytuat-ceremonia, ,Rocznik Muzealny”, t. IV, Włocławek.

Buksiński T. (1991), Zasady i metody interpretacji tekstów źródtowych, Wydawnictwo Naukowe UAM, Poznań. 
Czerwiński M. (2010), „IV Rzeczpospolita”, czyli o znaku w świecie kodu, w: Język IV Rzeczpospolitej, red. M. Czerwiński, P. Nowak, R. Przybylski, Wydawnictwo UMCS, Lublin.

Duda A. (2015), Orędzie z dnia 6 sierpnia 2015, http://www.prezydent.pl/aktualnosci/ wypowiedzi-prezydenta-rp/wystapienia/art,1,oredzie-prezydenta-rp-andrzeja-dudy-przed-zgromadzeniem-narodowym.html, 1.10.2015.

Geertz C. (2005), Wiedza lokalna. Dalsze eseje z zakresu antropologii interpretatywnej, Wydawnictwo Uniwersytetu Jagiellońskiego, Kraków.

Geertz C. (2007), Las symboli. Aspekty rytuałów u ludu Ndembu, Nomos, Kraków.

Górecki D. (1996), Ewolucja przepisów dotyczacych trybu wyboru prezydenta w polskim prawie konstytucyjnym, „Przegląd Sejmowy”, nr 2.

Karwat M. (2010), Polityczność i upolitycznienie. Metodologiczne ramy analizy, „Studia Politologiczne”, vol. 17.

Kretzer D. (2010), Rytuat, polityka, władza, Oficyna Wydawnicza Volumen, Warszawa.

Maroń G. (2012a), Instytucja przysięgi prezydenta w państwach europejskich, „Przegląd Prawa Konstytucyjnego", nr 1.

Maroń G. (2012b), Instytucja przysięgi prezydenta w polskim porzadku prawnym, „Przegląd Prawa Konstytucyjnego", nr 2.

Mezglewski A. (2011), Przysięga, ślubowanie oraz przyrzeczenie w prawie polskim, „Przegląd Prawa Wyznaniowego”, t. 3.

Mojak R. (1994), Instytucja Prezydenta RP w okresie przekształceń ustrojowych 1989-1992, Wydawnictwo Sejmowe, Warszawa.

Novak M. (1974), Choosing our King. Powerful Symbols in Presidential Politics, Macmillan, New York.

Orzechowski M. (1984), Polityka, władza i panowanie w teorii Maxa Webera, PWN, Warszawa.

Pożegnanie w pokoju 39. Wywiad z Januszem Strużyna, dyrektorem Biura Obsługi Organizacyjnej Prezydenta, „Gazeta Wyborcza” z dnia 31.07.2015.

Sarnecki P. (1999), Komentarz do art. 130, w: Konstytucja Rzeczypospolitej Polskiej. Komentarz, red. K. Działocha, L. Garlicki, Warszawa.

Shils E. (1965), Charisma, Order and Status, „American Sociological Review”, vol. 30 , nr 2 .

Sibora J. (2010), Protokół dyplomatyczny i ceremoniat państwowy II Rzeczypospolitej, Polski Instytut Spraw Międzynarodowych, Warszawa.

Sztompka P. (2002), Socjologia. Analiza społeczeństwa, Wydawnictwo Znak, Kraków.

Weber M. (2002), Gospodarka i społeczeństwo. Zarys socjologii rozumiejacej, PWN, Warszawa.

Wiszowaty M. (2015), Ceremonia inauguracji prezydentury - kiedyś i dziś, w Polsce i USA, http://www.konstytuty.pl/archives/2312, 1.10.2016. 


\section{Inauguration of Andrzej Duda's presidency as a set of legitimacy claims}

\section{Summary}

The author of this paper analyzes a specific political fact, namely the inauguration of presidency in modern democratic systems. Focusing on the inauguration of Andrzej Duda's presidency, the author answers the question of whether this extensive range of activities (encompassing the act of swearing in, symbolical acts, presidential address and other speeches) is an element of a consciously created legitimacy claim made by the president-elect. Answering this question in the affirmative, the author illustrates how the claims that refer to all three of Weber's types of legitimacy are encompassed in the successive parts of the inauguration: the swearing in refers to the legal element of legitimacy, an extensive range of symbolical acts refers to tradition, whereas the presidential address introduces yet another element justifying legitimacy, this time resulting from the heritage of Lech Kaczyński's charisma.

Key words: political rituals, political legitimacy, presidency, Andrzej Duda 
